\title{
GAMBARAN PENGETAHUAN DAN SIKAP REMAJA TENTANG HIV/AIDS DI SMA 24 BONE TAHUN 2018
}

\author{
Baderiah \\ AKBID Bina Sehat Nusantara Bone \\ Alamat korespondensi : (baderia_hm@yahoo.co.id/082344936786)
}

\begin{abstract}
ABSTRAK
Remaja merupakan masa peralihan dari masa anak ke masa dewasa yang ditandai oleh adanya perubahan fisik, emosi dan psikis. Masa remaja berlangsung antara usia 10-19 tahun, terjadi pematangan organ reproduksi yang sering disebut masa pubertas. Jumlah remaja di Kabupaten Bone pada tahun 2017 adalah 170.780 jiwa yang terdiri dari remaja laki-laki 86.637 jiwa $(50,73 \%)$ dan remaja perempuan 84.143 jiwa $(49,27 \%)$ yang mengalami HIV/AIDS sebanyak 7 jiwa. Berdasarkan data dari Kepala sekolah dan SMA 24 Bone, di dapatkan data siswi SMA 24 Bone sebanyak 90 siswi yang meliputi siswa laki laki 23 siswa (25,55\%) dan siswi perempuan 67 siswi $(74,44 \%)$. Tujuan : Diketahuinya gambaran pengetahuan dan sikap remaja tentang tentang HIV/AIDS di SMAN 24 Bone Tahun 2018. Metode : Penelitian ini menggunakan metode deskriptif dengan rancangan penelitian kuantitatif yang bertujuan untuk mendeskrepsikan atau menggambarkan suatu variabel tertentu, kemudian disajikan dalam bentuk tabel distribusi frekuensi. jumlah populasi dan sampel sebanyak 90 orang, laki-laki sebanyak 23 siswa dan perempuan sebanyak 67 siswi.

Hasil : dari 90 jumlah reponden terdapat $28(31,11 \%)$ jumlah remaja yang memiliki pengetahuan baik, yang memiliki pengetahuan kurang sebanyak $62(68,88 \%)$ remaja tentang HIV/AIDS dan terdapat 37 remaja $(41,11 \%)$ yang bersikap positif terhadap HIV/AIDS dan yang bersikap negatif terhadap HIV/AIDS sebanyak 53 remaja (358,88\%). Kesimpulan : Dari 90 jumlah remaja terdapat $28(31,11 \%)$ remaja yang memiliki pengetahuan baik dan $62(68,88 \%)$ remaja yang memiliki pengetahuan kurang tentang HIV/AIDS.
\end{abstract}

Kata Kunci : Sikap, pengetahuan, HIV/AIDS

\section{PENDAHULUAN}

Masa remaja merupakan masa yang sangat penting dalam perkembangan seseorang. Pada umumnya remaja didefinisikan sebagai masa peralihan dari masa kanak-kanak ke masa dewasa, yang memasuki usia kira-kira 10 hingga 12 tahun dan berakhir pada usia 18 tahun hingga 22 tahun, dan ditandai dengan perubahan dalam bentuk dan ukuran tubuh, fungsi tubuh, psikologi dan aspek fungsional.

Masa remaja disebut sebagai masa yang banyak masalah dikarenakan remaja sering mengalami kesulitan untuk mengatasi masalah-masalahnya. Hal ini terjadi karena remaja tidak terbiasa untuk menyelesaikan masalahnya sendiri dan sering lebih meminta bantuan orang lain, sehingga membuat dia menyelesaikan masalah bukan berdasarkan kemampuan atau keinginan.

Penyakit kelamin (Veneral Diseases) sudah lama dikenal di dunia. Seiring dengan kemajuan ilmu pengetahuan dan perkembangan peradaban masyarakat, semakin banyak pula ditemukan penyakitpenyakit baru, sehingga istilah diseases tidak sesuai lagi dan diubah menjadi Sexually Transmitetted Diseases atau Penyakit Menular
Seksual (PMS). Perubahan istilah tersebut membawa dampak terhadap luasnya ruang lingkup PMS.

Penyakit Menular Seksual (PMS) merupakan penyakit yang menular melalui hubungan seksual (kelamin). Penyakit menular ini akan lebih beresiko bila melakukan hubungan seksual dengan berganti-ganti pasangan baik melalui vagina, oral maupun anal. (Kusmiran Eny, 2012).

Human Immunodeficiency Virus (HIV) adalah virus yang menyerang kekebalan tubuh manusia, virus ini jenis retrovirus RNA dengan nama $T$-cel Lymphatropic virus. Virus yang masuk kedalam tubuh menyerang sel darah putih dan merusaknya sehingga sel darah putih yang berfungsi sebagai pertahanan terhadap infeksi akan menurun jumlahnya. Akibatnya sistem kekebalan tubuh menjadi lemah dan penderita mudah terkena berbagai penyakit (AIDS). (Feryanto Achmad Fadlun, 2013)

Acquired Immunodeficiency Syndrom (AIDS) adalah sindroma dengan gejala penyakit infeksi opurtinistik atau kanker tertetu akibat menurunnya sistem kekebalan tubuh oleh infeksi Human Immunodeficiency Virus.(Maryunani Anik, 2013) 
Berdasarkan data World Healt Organization (WHO) 2015 menunjukkan HIV/AIDS telah menjadi penyakit yang bersifat pandemik. Prevalensi terbesar dengan jumlah orang yang menderita HIV/AIDS 22,5 juta atau $68 \%$ dari jumlah di seluruh dunia terdapat di Afrika Sub-Sahara. Asia Tenggara berada di urutan ke dua dengan jumlah penderita HIV/AIDS sebanyak 4,1 juta orang. (ejournal keperawatan (e-Kp) Volume 1. Nomor 1. Agustus 2016, di akses pada tanggal 03 Juli 2018).

Dari data yang dihimpun oleh Kementrian Kesehatan Indonesia, terdapat pergerakan jumlah penderita HIV/AIDS yang naik turun. Data pada 2015, penderita HIV sebanyak 9.793 orang dan AIDS sebanyak 5.483 orang. Pada 2016, penderita HIV sebanyak 21.591 orang dan AIDS sebanyak 6.845 (ejournal keperawatan (e-Kp) Volume 1. Nomor 1. Agustus 2016, di akses pada tanggal 03 Juli 2018)

Menurut Komisi Penanggulangan AIDS (KPA) Sulawesi Selatan bahwa kejadian HIV/AIDS pada tahun 2016 berjumlah HIV 438 penderita dan AIDS 334 penderita. Pada tahun 2017 ditemukan kasus HIV sebanyak 8.192 orang dan AIDS sebanyak 3.518 orang. (diakses pada tanggal 03 Juli 2018)

Jumlah remaja di Kabupaten Bone pada tahun 2017 adalah 170.780 jiwa yang terdiri dari remaja laki-laki 86.637 jiwa $(50,73 \%)$ dan remaja perempuan 84.143 jiwa (49,27\%). Sedangkan jumlah remaja di Kecamatan Dua Boccoe tahun 2017 adalah 19.196 jiwa yang meliputi remaja laki laki 9.711 jiwa $(50,59 \%)$ dan remaja perempuan 9.485 jiwa $(49,41 \%)$ (Dinas Kesehatan Kabupaten Bone, 2017).

Berdasarkan data dari sekolah SMA 24 Bone, di dapatkan data siswi SMA 24 Bone sebanyak 90 siswi yang meliputi siswa laki laki 23 siswa $(25,55 \%)$ dan siswi perempuan 67 siswi $(74,44 \%)$. (Profil SMA 24 Bone tahun 2018).

Masa remaja terjadi peningkatan minat seksual yang membuat remaja selalu berusaha mencari lebih banyak informasi mengenai seks. Hanya sedikit remaja yang memperoleh informasi dari orang tuanya. Oleh karena itu, mereka selalu terdorong untuk mencari informasi seks melalui buku-buku seks dari temannya, internet, mengadakan eksprimen seksual, masturbasi, bercumbu atau melakukan senggama. Minat utama seks remaja adalah pada hubungan seks, konteks, dan perilaku seks.

Berdasarkan latar belakang di atas, maka peneliti tertarik untuk melakukan penelitian yang berjudul "Gambaran pengetahuan dan sikap remaja tentang HIVIAIDS di SMA 24 Bone Tahun 2018".

\section{BAHAN DAN METODE}

Lokasi, populasi dan sampel

Penelitian dilakukan di SMA 24 Bone Kec. Dua Boccoe.Penelitian dilaksanakan pada bulan Juli tahun 2018. Populasi dalam penelitian ini adalah semua siswa/siswi di sekolah SMA 24 Bone sebanyak 556 siswa/siswi. Jenis penelitian digunakan adalah adalah metode deskriptif dengan rancangan penelitian kuantitatif.

\section{Analisa Data}

Teknik analisa data aspek pengetahuan adalah menggunakan presentase. Selanjutnya data ditabulasi, diinterventasi kemudian diproses secara statistic.

\section{HASIL PENELITIAN}

Berdasarkan kasus diatas menunjukkan bahwa dari 90 jumlah reponden terdapat 28 $(31,11 \%)$ jumlah remaja yang memiliki pengetahuan baik, yang memiliki pengetahuan kurang sebanyak $62(68,88 \%)$ remaja tentang HIV/AIDS.Dari data tersebut diatas terdapat 37 remaja $(41,11 \%)$ yang bersikap positif terhadap HIV/AIDS dan yang bersikap negatif terhadap HIV/AIDS sebanyak 53 remaja $(358,88 \%)$.

Tabel. 1. Distribusi Frekuensi Pengetahuan Remaja Tentang HIV/AIDS Di SMA 24 Bone Kec. Dua Boccoe Tahun 2018. $(n=90)$

\begin{tabular}{|c|c|c|}
\hline Pengetahuan & $\mathrm{n}$ & $\%$ \\
\hline Baik & 28 & 31,11 \\
\hline Kurang & 62 & 68,88 \\
\hline Jumlah & 90 & 100 \\
\hline
\end{tabular}

Berdasarkan tabel 1 pengetahuan remaja di SMA 24 Bone Kec Dua Boccoe terhadap HIV/AIDS dengan pengetahuan baik sebesar $31,11 \%$ dan pengetahuan kurang sebesar $68,88 \%$.

Gambaro: 1 Diagram Frekuensi Pengetahuan Remaja Tentang HIV/AIDS Di SMA 24 Bone Kec. Dua Boccoe Tahun 2018

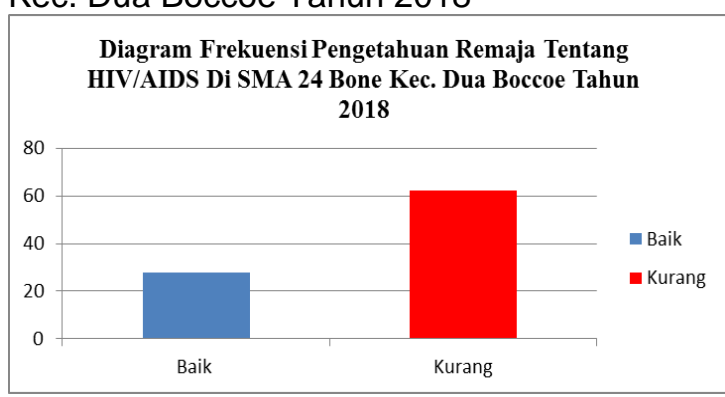


Tabel 2 Distribusi Frekuensi Berdasarkan Sikap Remaja Tentang HIV/AIDS di SMA 24 Bone Kec. Dua Boccoe Tahun 2018. $(n=90)$

\begin{tabular}{|c|c|c|}
\hline Sikap & Frekuensi & Persentase \\
\hline Positif & 37 & 41,11 \\
\hline Negatif & 53 & 58,88 \\
\hline Jumlah & 90 & 100 \\
\hline
\end{tabular}

Berdarakan tabel 2 dilihat bahwa sikap remaja di SMA 24 Bone Kec. Dua Boccoe terhadap HIV/AIDS dengan menunjukan sikap positif sebesar $41,11 \%$ dan sikap negative sebesar $58,88 \%$.

Gambaro: 2 Diagram Frekuensi Pengetahuan Remaja Tentang HIV/AIDS Di SMA 24 Bone Kec. Dua Boccoe Tahun 2018.

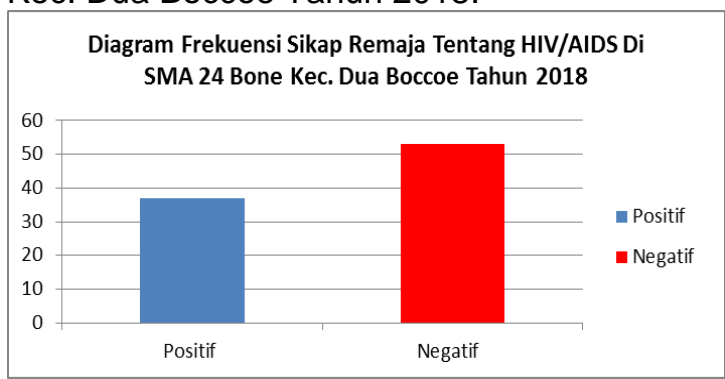

\section{PEMBAHASAN}

Dari tabel 1 menunjukkan bahwa dari 90 jumlah reponden terdapat $28(31,11 \%)$ remaja yang memiliki pengetahuan baik, yang memiliki pengetahuan kurang sebanyak 62 $(68,88 \%)$ remaja tentang HIV/AIDS.

Hasil penelitian ini sesuai dengan hasil penelitian yang dilakukan oleh Reiza 2016 tentang HIV/AIDS yaitu sebagian besar remaja memiliki pengetahuan yang kurang 96 responden $(63,8 \%)$. Pengetahuan merupakan komponen yang paling penting yang dapat menunjang sikap dan perilaku remaja terhadap pencegahan HIV/AIDS. Adapun beberapa hal yang perlu diperhatikan yaitu advokasi, pendidikan serta kebijakan program yang berkesinambungan.

Hasil penelitian ini sesuai dengan teori Widyastuti dkk (2015), Kebanyakan remaja tidak memiliki pengetahuan yang akurat tentang Penyakit Menular Seksual (PMS). Selain itu mereka juga tidak memiliki akses terhadap pelayanan dan informasi tentang PMS. Informasi biasanya hanya dari teman yang biasanya sering tidak akurat.

Pengetahuan dipengaruhi oleh proses pembelajaran. Proses pembelajaran sendiri dipengaruhi oleh berbagai faktor antara lain proses belajar, pengajar, metode yang digunakan, kurikulum, perpustakaan dan sebagainya, apabila faktor-faktor tersebut tersedia dengan baik maka proses belajar akan efektif dan hasil yang di capai akan optimal dan. pengetahuan akan meningkat. Menurut Notoatmodjo (2010), dengan memberikan informasi atau pesan-pesan kesehatan diharapkan masyarakat, kelompok atau individu dapat memperoleh pengetahuan tentang kesehatan yang baik.

Dari tabel 2 terdapat 37 remaja $(41,11 \%)$ yang bersikap positif terhadap HIV/AIDS dan yang bersikap negatif terhadap HIV/AIDS sebanyak 53 remaja (35,88\%). Penelitian ini sejalan dengan penelitian Arika Indah Setyar, 2016 didapatkan dari 67 remaja bahwa tingkat pengetahuan remaja

yang menjadi responden yang memiliki sikap pencegahan HIV/AIDS sebagian besar remaja menjawab tidak setuju pada pernyataan yang bersifat negatif sebesar $80,60 \%$ dan sebagian menjawab setuju pada pernyataan yang bersifat positif sebesar $19,40 \%$.

Hasil penelitian ini sesuai dengan hasil penelitian yang dilakukan oleh Reiza 2016 bahwa tingkat pengetahuan remaja tentang HIV/AIDS yaitu sebagian besar remaja memiliki pengetahuan yang kurang 96 responden $(63,8 \%)$. Pengetahuan merupakan komponen yang paling penting yang dapat menunjang sikap dan perilaku remaja terhadap pencegahan HIV/AIDS. Adapun beberapa hal yang perlu diperhatikan yaitu advokasi, pendidikan serta kebijakan program yang berkesinambungan.

Hasil penelitian ini sesuai dengan teori Widyastuti dkk (2015), Kebanyakan remaja tidak memiliki pengetahuan yang akurat tentang Penyakit Menular Seksual (PMS). Selain itu mereka juga tidak memiliki akses terhadap pelayanan dan informasi tentang PMS. Informasi biasanya hanya dari teman yang biasanya sering tidak akurat.

Pengetahuan dipengaruhi oleh proses pembelajaran. Proses pembelajaran sendiri dipengaruhi oleh berbagai faktor antara lain proses belajar, pengajar, metode yang digunakan, kurikulum, perpustakaan dan sebagainya, apabila faktor-faktor tersebut tersedia dengan baik maka proses belajar akan efektif dan hasil yang di capai akan optimal dan. pengetahuan akan meningkat. Menurut Notoatmodjo (2010), dengan memberikan informasi atau pesan-pesan kesehatan diharapkan masyarakat, kelompok atau individu dapat memperoleh pengetahuan tentang kesehatan yang baik.

Dari tabel 2 terdapat 37 remaja $(41,11 \%)$ yang bersikap positif terhadap HIV/AIDS dan yang bersikap negatif terhadap HIV/AIDS sebanyak 53 remaja (35,88\%). Penelitian ini sejalan dengan penelitian Arika Indah Setyar, 2016 didapatkan dari 67 remaja 
yang menjadi responden yang memiliki sikap pencegahan HIV/AIDS sebagian besar remaja menjawab tidak setuju pada pernyataan yang bersifat negatif sebesar $80,60 \%$ dan sebagian menjawab setuju pada pernyataan yang bersifat positif sebesar $19,40 \%$.

Perbedaan sikap pada remaja ini dapat dipengaruhi oleh kondisi masing- masing individu, cara pandang dan latar belakang. Jika dipahami penyebab perbedaan ini sifatnya sangat subyektif. Oleh karena itu, perbedaan sikap merupakan hal biasa dan harus dipahami sebagai bentuk keunikan tiap individu. Semakin berkembangnya pola pikir serta bertambahnya pengalaman bersama teman, keluarga dan masyarakat menjadikan remaja tersebut memilah mana yang baik dan mana yang buruk untuk dirinya sehingga terbentuk suatu sikap dalam diri remaja tersebut. Menurut Azwar (2010) bahwa faktor pengalaman pribadi juga dapat mempengaruhi pembentukan sikap seseorang. Dalam sikap positif, kecenderungan tindakan adalah mendekati, menyenangi, mangharapkan objek tertentu, sedangkan dalam sikap negatif terdapat kecenderungan untuk menjauhi, menghindari membenci, tidak menyukai objek tertentu (Sarwono, 2010).

Sikap dapat dipengaruhi oleh beberapa faktor, yaitu pengetahuan, pengalaman pribadi, pengaruh orang lain yang dianggap penting, pengaruh kebudayaan, media massa, lembaga pendidikan dan faktor emosional (Azwar, 2010).

\section{DAFTAR PUSTAKA}

Data Dinas Kesehatan Kabupaten Bone. 2017. Data Sekunder. Kab. Bone: Watampone.

ejournal keperawatan (e-Kp) Volume 1. Nomor 1. Agustus 2016, di akses pada tanggal 03 Juli 2018

Fadlun, Feryanto A. 2013. Asuhan kebidanan Patologis. Jakarta.: Salemba Medika

Kusmiran Eny, 2010. Kesehatan Reproduksi Remaja Dan Wanita. Jakarta : Salemba Medika.

Notoatmodjo, 2010. Metodologi penelitian. Yogyakarta : Nuha Medika

Profil Data SMA 24 Bone tahun 2018. Data Sekunder, Kab. Bone : WatamponeSafruddin A. B. 2012

Sarwono. 2010. Ilmu Kebidanan . Jakarta : Yayasan Bina Pustaka.

Supriadi 2014. Metodologi Penelitian Kebidanan. Nuha Medika : Yogyakarta.

. Bagi Pendidikan

\section{KESIMPULAN}

Dari 90 jumlah remaja terdapat 28 $(31,11 \%)$ remaja yang memiliki k terhadap HIV/AIDS

. Dari hasil penelitian ada $62(68,88)$ remaja yang memiliki pengetahuan kurang entang HIV/AIDS terhadap HIV/AIDS. Dari hasil penelitian a $53(58,88)$ remaja yang memiliki sikap kerjasama dengan Puskesmas agar pengetahuan siswi tentang HIV/AIDS di SMA 24 Bone Kecamatan Dua Boccoe dapat menjadi baik.

Dapat meningkatkan kualitas pendidikan bagi para mahasiswa dengan penyediaan prasarana yang mendukung peningkatan kemampuan mahasiswa sehingga dapat menghasilkan bidan yang professional. Juga dapat dijadikan sebagai menambah wawasan ilmu

. Bagi penulis

Penelitian ini sangat berguna untuk menambah pengalaman dan sebagai bahan untuk menerapkan ilmu yang didapatkan selama perkuliahan. 